The rivers are our brothers; they quench our thirst. The rivers carry our canoes, and feed our children. If we sell you our land, you must remember and teach your children, that the rivers are our brothers, and yours: and you must henceforth give the rivers the kindness you would give any brother.

We know that the White Man does not understand our ways. One portion of land is the same to him as the next, for he is a stranger who comes in the night and takes from the land whatever he needs. The earth is not his brother, but his enemy, and when he has conquered it, he moves on. He leaves his father's graves behind, and he does not care. He kidnaps the earth from his children and he does not care. His father's grave and his children's birthright are forgotten. He treats his mother, the Earth, and his brother, the sky, as things to be bought, plundered, sold like sheep or bright beads. His appetite will devour the earth and leave behind only a desert.

I do not know. Our ways are different from your ways. The sight of your cities pains the eyes of the Red Man. But perhaps it is because the Red Man is a savage and does not understand.

There is no quiet place in the White Man's cities. No place to hear the unfurling of leaves in spring, or the rustle of an insect's wings. But perhaps it is because I am a savage and do not understand. The clatter only seems to insult the ears. And what is there to life if a man cannot hear the lonely cry of the whippoorwill or the arguments of the frogs around a pond at night? I am a Red Man and do not understand. The Indian prefers the soft sound of the wind darting over the face of a pond, and the smell of the wind itself, cleansed by a mid-day rain, or scented with the piñon pine.

The air is precious to the Red Man, for all things share the same breath - the beast, the tree, the man, they all share the same breath. The White Man does not seem to notice the air he breathes. Like a man dying for many days, he is numb to the stench. But if we sell you our land, you must remember that the air is precious to us, that the air shares its spirit with all the life it supports. The wind that gave our grandfather his first breath also receives his last sigh. And if we sell you our land, you must keep it apart and sacred, as a place where even the White Man can go to taste the wind that is sweetened by the meadow's flowers.

So we will consider your offer to buy our land. If we decide to accept, I will make one condition: the White Man must treat the beasts of this land as his brothers.

I am a savage and I do not understand any other way. I have seen a thousand rotting buffaloes on the prairie, left by the White Man who shot them from a passing train. I am a savage and I do not understand how the smoking iron horse can be more important than the buffalo that we kill only to stay alive.

What is Man without the beasts? If all the beasts were gone, Man would die from a great loneliness of spirit. For whatever happens to the beasts, soon happens to Man. All things are connected.

You must teach your children that the ground beneath their feet is the ashes of our grandfather's. So that they will respect the land, tell your children that the earth is rich with the lives of our kin. Teach your children what we have taught our children, that the earth is our mother. Whatever befalls the earth befalls the sons of the earth. If men spit upon the ground, they spirt upon themselves.

This we know: the earth does not belong to Man: Man belongs to the earth. This we know. All things are connected, like the blood which unites one family. All things are connected. Whatever befalls the earth, befalls the sons of the earth. Man did not weave the web of life: he is merely a strand in it. Whatever he does to the web, he does to himself.

Even the White Man, whose God walks and talks with him as friend to friend, cannot be exempt from the common destiny... We may be brothers after all. We shall see. One thing we know, which the White Man may one day discover-our God is the same God. You may think now that you own Him as you wish to won our land; but you cannot. He is the God of Man, and His compassion is equal for the Red Man and the White. This earth is precious to Him, and to harm the earth is to heap contempt on its Creator. The White too shall pass; perhaps sooner than all other tribes. Contaminate your bed, and you will one night suffocate in your own waste.

But in your perishing you will shine brightly, fired by the strength of the God who brought you to this land and for some special purpose gave you dominion over this land and over the Red Man. That destiny is a mystery to us, for we do not understand when the buffaloes are all slaughtered, the wild horses are tamed, the secret corners of fhe forest heavy with scent of many men, and the view of the ripe hills blotted by talking wires. Where is the thicket? Gone. Where is the eagle? Gone. The end of living and be beginning of survival.'

[Communicated by]

Ayilam P. Venkateswaran, Ambassador Embassy of China

Beijing

China.

\title{
World Commission on Environment \& Development
}

The World Commission on Environment and Development (WCED), established following a resolution adopted by the United Nations General Assembly in December 1983 , is a 'new and independent body created to look ahead at critical environment and development problems and propose better ways and means for the world community to address them'. It held its inaugural meeting in Geneva, Switzerland, during 1-3 October 1984, and 'will make its recommendations for action to the General Assembly of the UN in 1987'. Despite the multiplicity of bodies already in the field (including our own World Council For The Biosphere and its twin International Society For Environmental Education), and other interests which often overlap and sometimes conflict with its initiative, the new Commission's work is to be conducted at such a level and in such a manner that we feel it should be supported and helped in every possible way - to have real clout with decision-makers everywhere.

The Chairman of the Commission is Mrs Gro Harlem Brundtland, Leader of the Opposition, former Prime Minister, and a former Minister of Environment, of Norway. The Vice-Chairman is Dr Mansour Khalid, former Foreign Minister of Sudan. The Commissioners include prominent political figures and leaders concerned with environment and development. They were selected by the Chairman and Vice-Chairman, and will serve in a personal capacity. When the Commission is complete, its full voting members will number 22, comprising 5 from Aisa, 5 from Africa, 4 from Latin America, 3 each from Western and Eastern Europe, and only 2 from North America-despite this last 
being so often the main source of pertinent expertise and hoped-for support, and apparently ignoring all of Australasia-Oceania.

The WCED Secretariat is led by Mr James MacNeill, who is responsible to the Chairman of the Commission and is himself an ex-officio member hailing from Canada. Financing of the World Commission is on the basis of voluntary contributions of funds or of services-in-kind from governments or other institutions and sources. Its accounts are subject to external audit. Japan, Sweden, Switzerland, Canada, Netherlands, Norway, Denmark, and Finland, were the first to pledge resources to WCED and their "contributions were sufficient to assure the Commission of the resources to start its work on a realistic scale'.

Establishment of WCED reflects a conviction that a future can be built which should be more prosperous or at least secure than the present-if only it can be made to depend on policies and practices that are both ecologically and economically sustainable. But what can such a Commission do that other agencies cannot? Among the advantages of the 'Commission approach' to such prospects we may cite the personal independence of its members, the stimulation of international processes of deliberation, and active mobilization of leading scientific and other specialists for guidance and advice with a focus on emerging or foreseeable challenges rather than on the short-term preoccupations of national governments.

The Commission aspires to draw on the best obtainable scientific and other advice for help in performing 'its principal task, namely: to re-examine the critical issues of environment and development and formulate new and concrete action proposals to deal with them; to assess and propose new forms of international cooperation that can break out of existing patterns and foster needed change; and to raise the level of understanding and commitment everywhere'. It intends to perform its work in as open and visible a manner as possible, holding meetings in many different parts of the world in order to "permit good regional access'; and 'it will call on the world's media both to popularize contributions received and the Commission's own work and, wherever practical, to provoke and gather new ideas and sound out public opinion'.

It is most ardently to be hoped that the Commission will take a firm stand on over-population, and also be effectively outspoken in dealing with military threats to the environment and to properly sustainable development.

In view of the close coincidence of many of our own efforts and hopes for the future, it is especially gratifying to welcome this large-scale operation alongside our primarily educational WCB-ISEE voluntary 'shoestring' ones which were featured widely in our last issue. The address of the World Commission on Environment and Development is: Palais Wilson, 52 rue des Paquis, 1201 Geneva, Switzerland-Tel. (022) 32.71.17; Telex $27910 \mathrm{csen} \mathrm{ch}$, where it is understood all serious contacts will be welcomed.

Nicholas POLUNIN

\section{Our Change of Address: But Not of Office, Abode, or Telephones}

Whereas the many from among our friends and collaborators who have graced our abode or visited our office since we moved in from the country more than a dozen years ago will, we sincerely hope, remember where we are usually to be found and will soon visit us again, we warn them that, although our abode and office remain the same, the name of the street on which we are situated, and also the number, have been changed by the authorities to 7 Chemin Taverney.

Our telephone numbers remain the same ([022] 982383 and 84 ) and so, we hope-with a benevolent 'assist' from
Father Time-do we. So for once (and for visitors and correspondents) I'll record our full address in these columns, hoping that any remaining confusion among would-be visitors and even dinner-guests will soon cease:

\author{
N. P. \\ THE FOUNDATION FOR ENVIRONMENTAL \\ CONSERVATION \\ 7 Chemin Taverney \\ 1218 Grand-Saconnex \\ Geneva, Switzerland.
}

\section{Threatened Plants and Animals of the World}

A nutritious nut that could help to save Ethiopia and Somalia from future famines, the world's smallest mammal, the largest butterfly, and the largest flower, have been chosen as representative of the world's most endangered species. They were among 12 plants and 12 animals identified as among the world's most endangered species by the International Union for Conservation of Nature and Natural Resources (IUCN) at its General Assembly in Madrid on 14 November 1984.

The Yeheb Nut-bush (Cordeauxia edulis) grows in the arid lands of the Horn of Africa. In 1929 it constituted up to half of the woody vegetation in many areas of Somalia, but it is now much reduced and its existence is threatened by drought, overgrazing by goats, and war, although the Somali National Range Agency has now set aside reserves. Heavy harvesting of seed and browsing by goats severely reduce the chances of natural regeneration, though great interest has been expressed in its potential as a source of food.
The Bumblebee Bat (Craseonycteris thonglongyai), the world's smallest mammal, only became known to science in 1974. It weighs only two grams and really is only as big as a large bumblebee. It lives in remote limestone caves in Thailand, and its existence could be threatened by museum and zoo collectors. Moreover, proposed hydroelectric projects menace this tiny Bat's cave habitat.

The Giant Rafflesia (Rafflesia arnoldii), a metre-wide parasitic flower, is threatened by destruction of the rainforest in Sumatra, while the world's largest butterfly is now severely threatened by expanding oil-palm and logging industries. It is Queen Alexandra's Birdwing (Ornithoptera alexandrae), of Papua New Guinea.

The representative threatened species were selected by scientists under the aegis of IUCN's Species Survival Commission, who declared that priority action was required to save them from extinction. Mr Grenville Lucas, Chairman of the Commission, declared: 'More than 1,000 vertebrate species are in danger of extinction, including many specta- 